УДК 611.131/.14-091.8-02:616.395]-092.9

DOI 10.11603/1811-2471.2018.v0.i3.9273

\title{
ОСОБЛИВОСТІ СТРУКТУРНО-ПРОСТОРОВОЇ ОРГАНІЗАЦІї КРОВОНОСНОГО РУСЛА ЛЕГЕНЬ ЩУРІВ У НОРМІ ТА ЙОГО РЕОРГАНІЗАЦІЯ ПРИ ЗАГАЛЬНОМУ ЗНЕВОДНЕННІ
}

\author{
๑М. О. Вацик \\ ДВНЗ «Тернопільський державний медичний університет імені І. Я. Горбачевського МОз України»
}

РЕзюмЕ. Експериментальне моделювання різноманітних захворювань на тваринах $\epsilon$ одним із основних методів вивчення закономірностей розвитку патологічних процесів, що часто трапляються у клінічній практиці. Для об'єктивної порівняльної оцінки експериментальних даних та їх наступної екстраполяції на людину важливо знати основні морфометричні параметри органів і тканин у нормі. Щодо загального зневоднення, то воно виникає внаслідок найрізноманітніших фізіологічних та патологічних станів і може бути причиною тяжких порушень у різних органах, включаючи легені.

Мета дослідження - встановити особливості структурно-просторової організації кровоносного русла легень щурів у нормі та дати кількісну характеристику змін його окремих параметрів при загальному зневодненні.

Матеріали і методи. Експерименти проведено на білих лабораторних статевозрілих щурах-самцях, яким моделювали загальну дегідратацію різного ступеня важкості. Дослідження проводили 3 використанням рентгенангіографічних, гістологічних, морфофметричних і статистичних методик.

Результати. За результатами проведеного дослідження було встановлено певні видові особливості структурної організації легеневої тканини і кровоносного русла легень у щурів і дана їх кількісна оцінка. До цих особливостей належать співвідношення між правою і лівою легенями за об'ємом і масою, поділ на частки кожної із легень та відповідне галуження їх кровоносних судин. Особливістю $є$ також досить часте виявлення артерій «замикаючого» типу. При тривалому загальному зневодненні відмічено висхідну вазоконстрикцію з одночасним зниженням пропускної спроможності гілок легеневих артерій дрібного і середнього калібру та розширенням просвіту і збільшенням ємності інтраорганних артерій великого калібру.

Висновки. 1. У щурів права легеня за об'ємом і масою значно переважає ліву, їх співвідношення складає 2,22 до 1,00. 2. Особливістю легень щурів $€$ їх поділ на частки: права поділяється на 4 частки, у лівій частковий поділ не виражений, що визначає особливості галуження правої і лівої легеневих артерій. 3. Тривале загальне зневоднення призводить до зниження пропускної здатності кровоносних русел легень за рахунок підвищення тонусу і звуження просвіту гілок легеневих артерій дрібного і середнього калібру, а також бронхіальних артерій з одночасним розширенням просвіту і збільшенням ємності інтраорганних артерій великого калібру.

КлючовІ СлОВА: експеримент; норма; загальне зневоднення; легені; артерії; морфометрія.

Вступ. Експериментальне моделювання на тваринах різноманітних захворювань є одним із основних методів вивчення закономірностей розвитку патологічних процесів, що часто трапляються у клінічній практиці $[1,2]$. Зокрема, подібність структурної організації органів та тканин щурів до органів і тканин людини дозволяє широко використовувати їх в експериментальній медицині [35]. Для об'єктивної порівняльної оцінки експериментальних даних та їх наступної екстраполяції на людину важливо знати особливості структурної організації органів і тканин та їх основні морфометричні параметри у нормі.

Щодо загального зневоднення, то воно виникає внаслідок найрізноманітніших фізіологічних та патологічних станів [6] і може бути причиною тяжких порушень в різних органах, включаючи легені $[7,8]$. Безпосереднім наслідком зневоднення буває зменшення об'єму циркулюючої крові з подальшим відповідним порушенням пери- ферійного кровотоку та розвитком циркуляторної гіпоксії $[9,10]$.

Мета дослідження - встановити особливості структурно-просторової організації кровоносного русла легень щурів у нормі та дати об'єктивну кількісну характеристику змін його окремих параметрів при загальному зневодненні.

Матеріал і методи дослідження. Експерименти проведено на 42 білих лабораторних статевозрілих щурах-самцях з масою тіла 160-180 г віком 2,5-3 місяці. 3 них 12 тварин склали контрольну групу, іншим 30 щурам загальну дегідратацію моделювали шляхом годування сухим вівсом без доступу до води протягом 3, 6 і 10 діб (загальне зневоднення легкого, середнього і тяжкого ступенів відповідно). Така модель широко застосовується в експерименті $[11,12]$.

Усі експериментальні дослідження проводили відповідно до принципів біоетики, що викладені у Гельсинській Декларації та Законі України 
Огляди літератури, оригінальні дослідження, погляд на проблему, ювілеї

«Про захист тварин від жорстокого поводження» (№ 1759-VI від 15.12.2009).

Рентгенангіографію проводили після ін'єкції артеріального русла малого кола кровообігу дрібнодисперсним водним зависом свинцевого сурика. На рентгенангіограмах визначали діаметр (D) і довжину (L) сегментів легеневої артерії в галуженнях 2-го і 3-го порядків, а також вираховували їх довжинно-діаметральні співвідношення (L/D).

Матеріал для гістологічного дослідження (шматочки легень) після забору фіксували у 10 \% нейтральному формаліні. Гістологічні зрізи забарвлювали гематоксиліном і еозином та за Ван Гізон.

Морфометричні дослідження включали визначення показника функціональної активності стінок артерій - індексу Вогенворта (IB) [13], як відношення площі середнього шару артерій до площі їх просвіту:

$$
\text { IB = (SM / Sחp }) 100 \%,
$$

де $S M-$ площа медії (середньої оболонки);

SПр-площа просвіту судини.

Для цього за допомогою окуляр-мікрометра MOB-1-15× визначали величини зовнішнього (D зовн.) і внутрішнього (D внутр.) діаметрів та розраховували товщину м'язової оболонки (TM).

Отриманий при проведенні досліджень цифровий матеріал піддавали статистичній обробці за допомогою Microsoft Exel for Windows 98 із визначенням середніх величин та їх стандартних похибок. Достовірність оцінювали за коефіцієнтом Стьюдента (t) при $\mathrm{p}<0,05$.

Результати й обговорення. Особливість структурно-просторової організації кровоносного русла легень щурів визначається насамперед

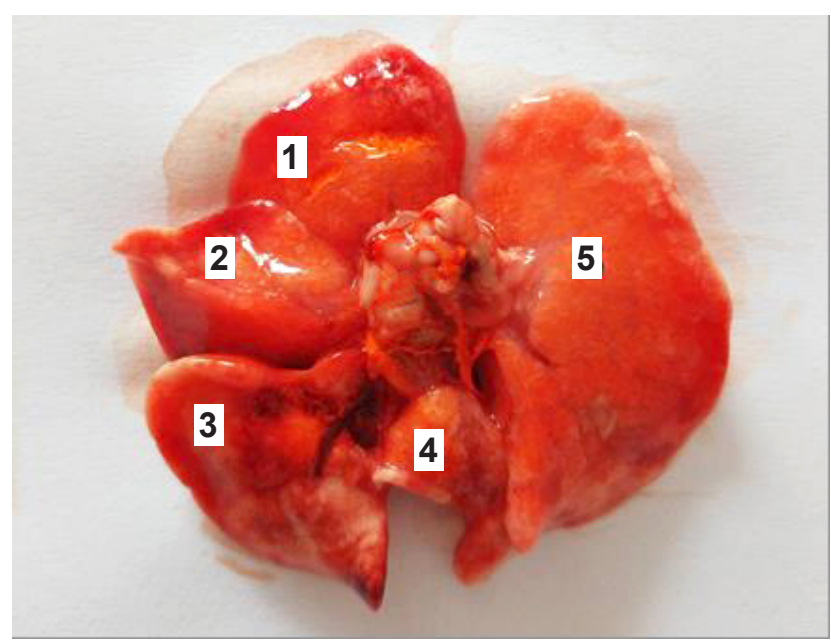

Рис. 1. Часткова будова легень щура. Краніальна (верхівкова) частка правої легені - 1; середня (серцева) частка правої легені - 2; каудальна (діафрагмальна) частка правої легені - 3; додаткова частка правої легені - 4; ліва легеня - 5. Фото з макропрепарата. анатомічною особливістю їх поділу на частки. На відміну від людей, права легеня у щурів має чотири частки, які розділені між собою міжчастковими щілинами: краніальна (верхівкова), середня (серцева), каудальна (діафрагмальна) і додаткова. Особливістю лівої легені $€$ відсутність чітких міжчасткових щілин і, відповідно чіткого поділу на частки, хоча за зовнішнім виглядом її можна поділити на верхню та нижню частини (рис. 1). Середня маса кожної із легень складала: правої $(1,15 \pm 0,04)$ г, лівої - $(0,52 \pm 0,03)$ г. Тобто як за масою, так і за об'ємом права легеня значно переважає над лівою. За результатами наших досліджень їх співвідношення у процентному вираженні складає: на праву легеню припадає $69 \%$, а на ліву $31 \%$, або 2,22 до 1,00.

Відповідно до часткової будови легень поділ основних стовбурів легеневих артерій також включає краніальну (верхівкову), середню (серцеву), каудальну (діафрагмальну) і додаткову часткові гілки (рис. 2).

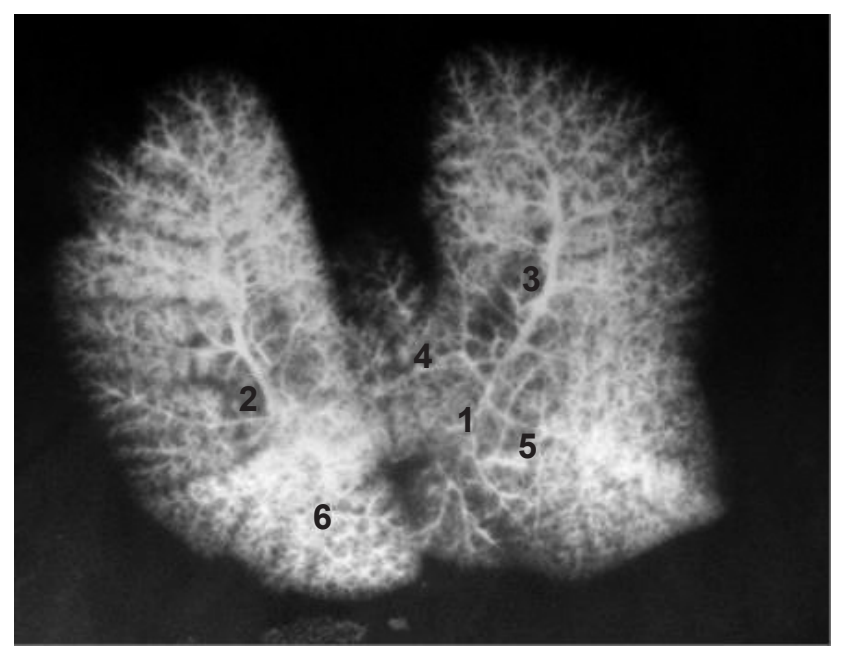

Рис. 2. Галуження легеневих артерій інтактного щура. Права легенева артерія - 1; ліва легенева артерія - 2; артерія краніальної (верхівкової) частки правої легені - 3; артерія середньої (серцевої) частки правої легені - 4; артерія каудальної (діафрагмальної) частки правої легені - 5; артерія додаткової частки правої легені - 6. Фото з рентгенангіограми.

Наступними є сегментарні, часточкові і підчасточкові артерії та кровоносні судини респіраторного відділу. При порівнянні довжини, діаметра і довжинно-діаметральних співвідношень встановлено, що на рівні другого порядку галуження (часткові артерії) їх середня довжина до наступної біфуркації складає $(3,15 \pm 0,02)$ мм, діаметр - $(1,44 \pm 0,02)$ мм і, відповідно, довжинно-діа-

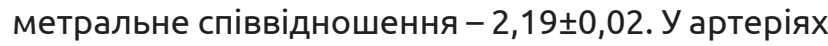
третього порядку галуження (сегментарні артерії) ці показники становлять відповідно $(2,24 \pm 0,01)$ мм, $(0,66 \pm 0,01)$ мм і $(3,37 \pm 0,02)$ мм. Тобто, при змен- 
Огляди літератури, оригінальні дослідження, погляд на проблему, ювілеї

шенні довжини і діаметра кожної наступної градації біфуркацій довжинно-діаметральні співвідношення зростають.

У щурів, як і всіх ссавців, легені мають подвійне кровопостачання: судини малого кола кровообігу (легеневі артерії і вени), які забезпечують газообмін та трофіку паренхіми легень, і судини великого кола кровообігу (бронхіальні артерії), які забезпечують киснем і поживними речовинами стінки бронхів і строму органа.

Гістологічно права і ліва артерії належать до судин еластичного типу, тобто основу їх стінок складають еластичні волокна. Судини наступних порядків (часткові і сегментарні артерії) $є$ артеріями змішаного типу: в них поступово втрачаються еластичні волокна і наростає питома вага гладком'язових елементів. Їх можна віднести до судин розподілу. Починаючи з часточкових артерій, і до артеріол, - це судини м'язового типу, або судини опору, у яких практично відсутні еластичні волокна.
Інтраорганні артерії малого кола кровообігу супроводжують галуження бронхів. На відміну від них, вени, від найдрібніших і до сегментарних, проходять на певній відстані у паренхімі і лише на рівні сегментів і часток наближаються до бронхів. У просторовому відношенні артерії розташовуються переважно над бронхами, а вени - дещо нижче від них. Морфофункціонально легеневі артерії за своєю будовою і кількісними показниками відповідають уявленню про те, що мале коло кровообігу $\epsilon$ зоною порівняно низького тиску. Тобто товщина їх стінки значно менша від товщини стінок зіставних з ними за діаметром артерій великого кола кровообігу.

Товщина і кількість шарів гладком'язових волокон середньої оболонки артерій по мірі зменшення калібру судин поступово зменшуються, однак показник їх функціонального стану, індекс Вогенворта, навпаки, зростає (табл. 1). Це свідчить про те, що зі зменшенням діаметра гілок легеневих артерій їх вазомоторні можливості посилюються.

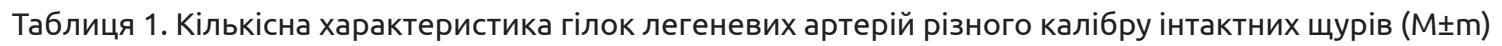

\begin{tabular}{|l|c|c|c|}
\hline \multirow{2}{*}{\multicolumn{1}{|c|}{ Показник }} & \multicolumn{3}{c|}{ Калібр судин } \\
\cline { 2 - 4 } & $\begin{array}{c}\text { крупні } \\
(126-150 \text { мкм })\end{array}$ & $\begin{array}{c}\text { середні } \\
(51-125 \text { мкм })\end{array}$ & $\begin{array}{c}\text { дрібні } \\
(26-50 \text { мкм })\end{array}$ \\
\hline D зовнішній, мкм & $144,67 \pm 1,20$ & $88,17 \pm 0,95$ & $36,33 \pm 0,76$ \\
\hline D внутрішній, мкм & $95,50 \pm 0,67$ & $55,50 \pm 0,89$ & $21,67 \pm 0,67$ \\
\hline TM, мкм & $24,58 \pm 0,30$ & $16,33 \pm 0,11$ & $7,33 \pm 0,11$ \\
\hline Індекс Вогенворта & $129,47 \pm 1,25$ & $152,64 \pm 3,15$ & $182,32 \pm 6,79$ \\
\hline
\end{tabular}

Разом з тим, іноді в окремих місцях, зокрема у товщі скупчень лімфоїдної тканини, можна було спостерігати артерії дрібного калібру з особливо потовщеними стінками і звуженим просвітом, тобто артерії «замикаючого» типу (рис. 3).

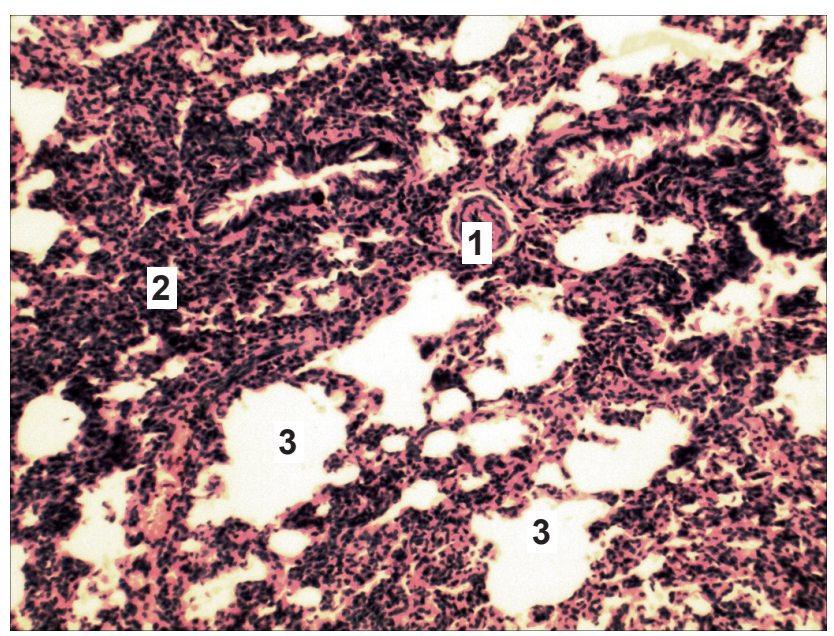

Рис. 3. Гістологічний зріз легені інтактного щура. Гілка легеневої артерії «замикаючого» типу - 1; лімфоїдна тканина-2; просвіт альвеол-3. Забарвлення гематоксиліном і еозином. 36. ×280.
У таких артеріях був досить чітко виражений внутрішній шар поздовжньо орієнтованих гладком'язових клітин і менш виражений зовнішній шар з циркулярною орієнтацією. Інколи у них просвіт зовсім не визначався і клітини внутрішньої ендотеліальної оболонки тісно дотикалися одна до одної по усьому периметру. Наявність таких артерій надає кровоносному руслу малого кола кровообігу здатності реагувати у широкому діапазоні в плані перерозподілу і забезпечення активності кровотоку залежно від інтенсивності фізичного навантаження.

Ще більш функціонально активними за кількісними показниками можна вважати бронхіальні артерії. У судинах із зовнішнім діаметром $(44,00 \pm 0,68)$ мкм їх внутрішній діаметр складав $(25,33 \pm 0,49)$ мкм. Відповідно до цього, товщина середньої оболонки сягала $(9,33 \pm 0,17)$ мкм, а ін-

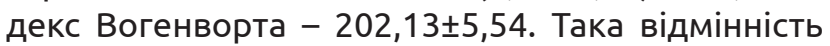
обумовлена, насамперед, вищим гемодинамічним навантаженням на бронхіальні артерії, порівняно з легеневими (рис. 4).

Бронхіальні артерії, як і легеневі, супроводжують галуження бронхів. Їх можна розрізнити як за 
Огляди літератури, оригінальні дослідження, погляд на проблему, ювілеї

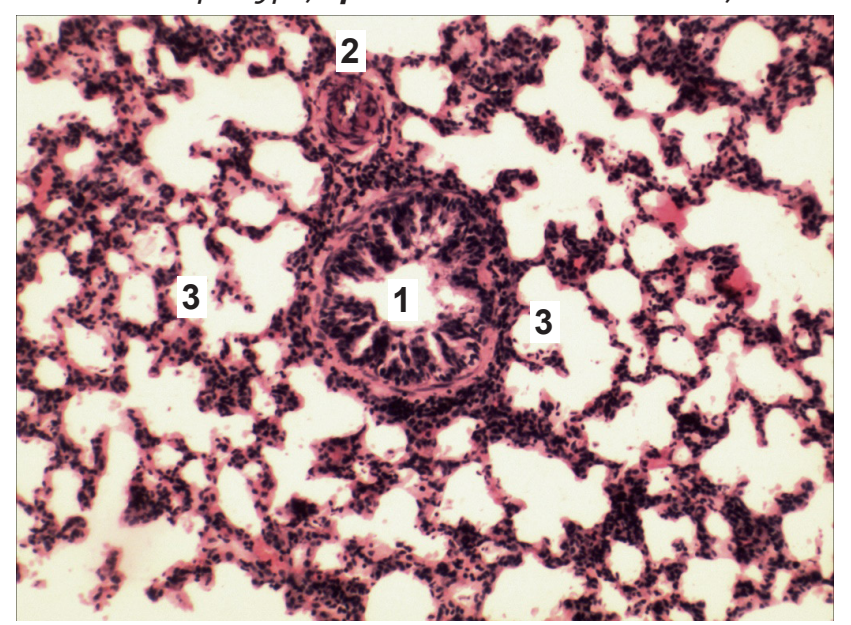

Рис. 4. Гістологічний зріз легені інтактного щура. Забарвлення гематоксиліном і еозином. 36. ×140. Просвіт сегментарного бронха - 1; гілка бронхіальної артерії-2; просвіт альвеол -3 .

діаметром (легеневі артерії крупніші), так і за товщиною стінки (бронхіальні артерії більш товстостінні), а також за тим, що легеневі артерії відді- лені від стінок бронхів різної товщини скупченнями лімфоїдної тканини, тоді, як бронхіальні артерії мають спільну з бронхами сполучнотканинну оболонку.

При аналізі кількісних показників контрастних рентгенангіограм через три доби експерименту привертала увагу тенденція до зменшення рівня показника довжинно-діаметральних співвідношень, яка у судинних галуженнях 2-го порядку була наслідком поступового зростання діаметра артерій при стабільній величині довжини судинних сегментів між біфуркаціями (табл. 2).

У галуженнях 3-го порядку зростали обидва лінійних показники. Проте за рахунок більшої інтенсивності зростання діаметра просвіту судин, порівняно із зростанням показника їх довжини, довжинно-діаметральні співвідношення також набували тенденції до зниження. На 3 добу спостереження зниження показника довжинно-діаметрального співвідношення у судинних галуженнях 2-го порядку сягало 1,83 \%, у галуженнях 3-го порядку $-1,79 \%$.

Таблиця 2. Характер зміни довжинно-діаметральних співвідношень галужень легеневих артерій у щурів за

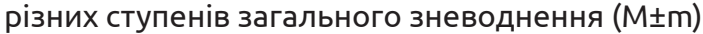

\begin{tabular}{|l|c|c|c|c|c|c|}
\hline \multirow{2}{*}{$\begin{array}{c}\text { Тривалість спосте- } \\
\text { реження }\end{array}$} & \multicolumn{3}{|c|}{ Галуження 2-го порядку } & \multicolumn{3}{c|}{ Галуження 3-го порядку } \\
\cline { 2 - 7 } & $\mathrm{L}$ & $\mathrm{D}$ & $\mathrm{L} / \mathrm{D}$ & $\mathrm{L}$ & $\mathrm{D}$ & $\mathrm{L} / \mathrm{D}$ \\
\hline Контроль & $3,15 \pm 0,02$ & $1,44 \pm 0,01$ & $2,19 \pm 0,02$ & $2,24 \pm 0,01$ & $0,66 \pm 0,01$ & $3,37 \pm 0,02$ \\
\hline 1 до6а & $3,14 \pm 0,04$ & $1,45 \pm 0,01$ & $2,16 \pm 0,03$ & $2,24 \pm 0,01$ & $0,67 \pm 0,01$ & $3,35 \pm 0,03$ \\
\hline 3 до6и & $3,15 \pm 0,03$ & $1,46 \pm 0,01$ & $2,15 \pm 0,03$ & $2,25 \pm 0,01$ & $0,68 \pm 0,01$ & $3,31 \pm 0,04$ \\
\hline 6 ді6 & $3,16 \pm 0,03$ & $1,48 \pm 0,02$ & $2,13 \pm 0,03$ & $2,26 \pm 0,02$ & $0,65 \pm 0,01$ & $3,46 \pm 0,04$ \\
\hline 10 ді6 & $3,17 \pm 0,02$ & $1,50 \pm 0,01^{*}$ & $2,11 \pm 0,02^{*}$ & $2,26 \pm 0,01$ & $0,64 \pm 0,01$ & $3,53 \pm 0,04^{*}$ \\
\hline
\end{tabular}

Примітка. * $-\mathrm{P}<0,05$.

Певні особливості і відмінності морфофункціональних реакцій кровоносних судин легень реєструвалися і через шість діб експерименту (загальне зневоднення середнього ступеня тяжкості). Якщо на контрастних рентгенангіограмах у З-денний термін реєструвалося зменшення рівня довжиннодіаметральних співвідношень, як на рівні гілок 2-го, так і 3-го порядків галуження, то у 6-денний термін, при збереженні динаміки цього показника у гілках 2-го порядку (подальше зниження на 2,74\%, порівняно з контролем), у гілках 3-го порядку він, навпаки, набував тенденції до зростання і вже перевершував контрольні цифри на 2,67 \% (див. табл. 2).

У 10-денний термін експерименту (зневоднення тяжкого ступеня) рентгенангіографічно, особливості морфофункціональної перебудови артеріального відділу кровоносного русла малого кола кровообігу, які були виявлені у 6-денний термін, зберігалися і наростали. За рахунок достовірного збільшення діаметра (на 4,17 \%) достовірно зменшувалася величина довжинно-діаметральних спів- відношень (на 3,66 \%) в галуженнях 2-го порядку. В галуженнях 3-го порядку, навпаки, величина довжинно-діаметральних співвідношень збільшувалася (на 4,75 \%), як за рахунок збільшення довжини сегментів артерій, так і за рахунок зменшення їх діаметра. Зменшення діаметра просвіту сегментарних артерій і артерій наступних порядків галужень призводило до зниження їх контрастування i, відповідно, до розрідження судинного рисунка, особливо у периферійних зонах. За рахунок цього також розширювалися рентгенологічні проміжки між окремими сегментами (рис. 5).

При гістологічному дослідженні характерною особливістю впливу загального зневоднення на стан кровоносного русла легень була наростаюча вазоконстрикція дрібних і середніх гілок легеневих артерій з одночасним збільшенням ємності інтраорганних гілок великого калібру, що стало безпосереднім підтвердженням результатів рентгенангіографічного дослідження. При цьому у артеріях дрібного калібру через 10 діб від початку експери- 
Огляди літератури, оригінальні дослідження, погляд на проблему, ювілеї

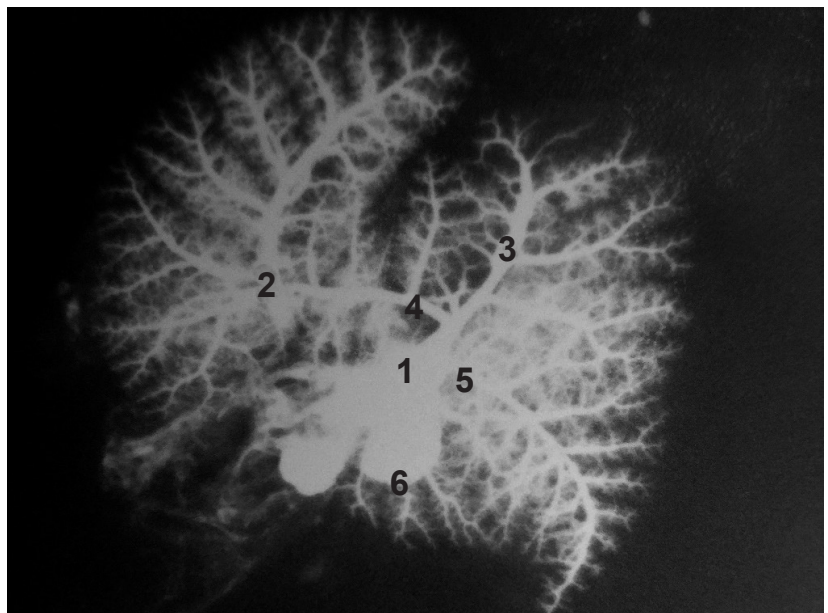

Рис. 5. Галуження легеневих артерій щура через 10 діб моделювання загального зневоднення. Права легенева артерія - 1; ліва легенева артерія - 2; артерія краніальної (верхівкової) частки правої легені - 3; артерія середньої (серцевої) частки правої легені - 4; артерія каудальної (діафрагмальної) частки правої легені - 5; артерія додаткової частки правої легені -6. Фото з ренгенангіограми.

менту за рахунок підвищення тонусу і гіпертрофічних процесів у середній гладком'язовій оболонці її товщина, порівняно з контролем, достовірно збільшувалася до $(8,83 \pm 0,25)$ мкм (на $20,46 \%$ порівняно 3 контролем) 3 відповідним достовірним збільшенням до $(275,56 \pm 6,50)$ мкм індексу Вогенворта (на 51,14 \% порівняно з контролем). У артеріях середнього калібру такий приріст вже також складав 4,59 \% і 9,35 \%, порівняно з контролем (збільшення до $(17,08 \pm 0,15)$ мкм і $(166,91 \pm 4,02)$ мкм) відповідно (в обох випадках $\mathrm{P}<0,05)$.

В артеріях крупного калібру, як і у попередній термін спостереження, продовжувала наростати їх ємність за рахунок розширення просвіту з одночасним звуженням товщини середньої оболонки, що підтверджувалося подальшим достовірним зниженням їх кількісних показників: товщини медії (середньої оболонки) до $(23,50 \pm 0,18)$ мкм на (4,40 \% порівняно з контролем) і рівня індексу Вогенворта до $(118,98 \pm 1,58)$ мкм (на 8,11 \% порівняно з контролем) (в обох випадках Р <0,05).

Досить часто, особливо у ділянках дисателектазів, спостерігали артерії дрібного калібру $з$ особливо потовщеними стінками, тобто артерії «замикаючого» типу, довкола яких формувалися сполучнотканинні муфти з просочуванням клітинами лімфоїдного ряду (рис. 6).

Виражено наростала також товщина серед-

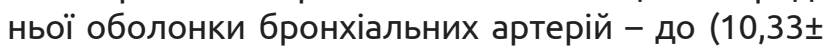
0,11) мкм (на 10,72 \% при $\mathrm{P}<0,05$ порівняно 3 контролем) і, відповідно, індекс Вогенворта - до $(247,43 \pm 7,86)$ мкм (на 22,41 \% при P < 0,05 порівняно з контролем). Причому нерідко потовщення сті-

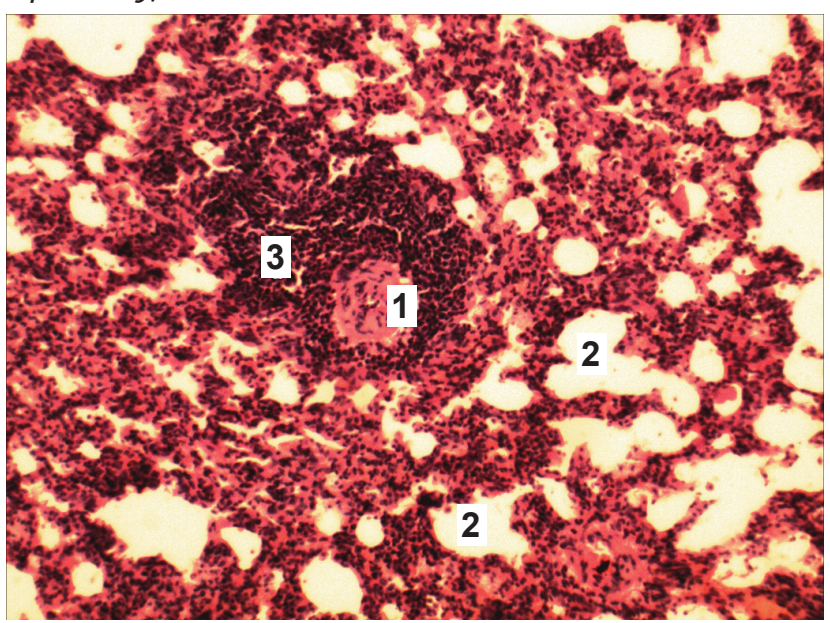

Рис. 6. Гістологічний зріз легені щура через 10 діб моделювання загального зневоднення. Артерія «замикаючого» типу - 1; просвіт альвеол - 2; лімфоїдна тканина - 3. Забарвлення гематоксиліном і еозином. 36. ×140.

нок бронхіальних артерій було нерівномірним за рахунок формування у них і гіпертрофії, крім циркулярних гладком'язових волокон пучків косо-поздовжнього і поздовжнього спрямування.

Результати проведеного дослідження свідчать про певні видові особливості структурної організації легеневої тканини і кровоносного русла легень у щурів, які треба враховувати при моделюванні експериментальної патології, щоб у подальшому з відповідною часткою достовірності їх можна було екстраполювати на людину. До цих особливостей належать співвідношення між правою і лівою легенями за об'ємом і масою, поділ на частки кожної із легень та відповідне галуження їх кровоносних судин. Особливістю є також досить часте виявлення артерій «замикаючого» типу.

При тривалому загальному зневодненні спостерігається висхідна вазоконстрикція з одночасним зниженням пропускної спроможності артерій дрібного і середнього калібру та розширенням просвіту ізбільшенням ємності інтраорганних артерій великого калібру.

Висновки. 1.У щурів права легеня за об'ємом і масою значно переважає над лівою і їх співвідношення складає 2,22 до 1,00.

2. Особливістю легень щурів $\epsilon$ їх поділ на частки: права поділяється на 4 частки, у лівій частковий поділ не виражений, що визначає особливості галуження правої і лівої легеневих артерій.

3. Тривале загальне зневоднення призводить до зниження пропускної спроможності кровоносних русел легень за рахунок підвищення тонусу і звуження просвіту гілок легеневих артерій дрібного і середнього калібру, а також бронхіальних артерій, з одночасним розширенням просвіту і збільшенням ємності інтраорганних артерій великого калібру. 
Огляди літератури, оригінальні дослідження, погляд на проблему, ювілеї

Перспективи подальших досліджень. Подальші дослідження дозволять розробити і об- ґрунтувати оптимально ефективні методи регідратації після загального зневоднення.

\section{ЛІТЕРАТУРА}

1. Давыдовский И. В. Проблема причинности в медицине (этиология) / И. В. Давыдовский. - М. : Медгиз, 1962. - С. 137-140.

2. Саркисов Д. С. Воспроизведение болезней человека в эксперименте / Д. С. Саркисов, П. И. Ремезов ; под ред. А. А. Вишневского. - М., 1960. - 780 с.

3. Лейтес А. Пластичность кровеносных сосудов сердца и легких / А. Лейтес, Ю. Шидаков. - Фрунзе : Кыргизстан, 1972. - 286 с.

4. Шляховер В. Е. Количественная характеристика структурной организации миокарда собаки / В. Е. Шляховер, Н. И. Яблучанский, В. И. Шевченко // Кровообращение. - 1983. - Т. 16, № 2. - С. 3-6.

5. Schaper G. Ultrastructural morhometric analysis of myocardium from dogs, rats, hamsters, mice and from human hearts / G. Schaper, E. Meiser, G. Stammler // Circ. Res. - 1985. - Vol. 56, No. 3. - P. 377-391.

6. Кіптенко Л. І. Морфологічні зміни внутрішніх органів щурів в умовах клітинної дегідратації на тлі посттравматичної регенерації великогомілкової кістки / Л. І. Кіптенко, Л. В. Васько, О. М. Гортинська // Світ медицини та біології. - 2013. - № 2. - С. 41-43.

7. Нетюхайло Л. Г. Водно-сольовий обмін (огляд літератури) / Л. Г. Нетюхайло, В. Л. Філатова, О. В. Філатова // Вісник проблем біології і медицини. - 2012. Вип. 1 (91). - С. 28-33.

8. Сапожніков О. П. Морфологічні й ультраструктурні зміни у легенях щурів молодого віку за умов впливу загальної дегідратації / О. П. Сапожніков, О. С. Максимова // Морфологічні дослідження - виклики сучасності. Збірник тез доповідей Науково-практичної конференції (Суми, 23-24 квітня 2015 року). - Суми : Сумський державний університет, 2015. - С. 76.

9. Патофізіологія / За ред. М. Н. Зайка і Ю. В. Биця. 2-ге вид., перероб. і доп. - К. : Медицина, 2008. C. 373-377.

10. Нагорная Н. В. Семинар: токсикозы у детей / Н. В. Нагорная // Здоровье ребенка. - 2011. - № 1 (28). C. 7-15.

11. Бумейстер В. І. Електронномікроскопічна картина регенерату великогомілкової кістки щурів за дії позаклітинного зневоднення / В. І. Бумейстер // Клінічна та експериментальна патологія. - 2009. - Т. 8, № 2. C. 10-13.

12. Гусейнова С. Т. Морфологические изменения в имунных образованиях тонкой кишки при дегидратации и коррекции физраствором / С. Т. Гусейнова // Вестник новых медицинских технологий. - 2009. - Т. 16, № 2. - С. 199-200.

13. Изменение активности нейрокининовой системы в слизистой оболочке верхних дыхательных путей крыс при моделировании хронического табакокурения / Ю. Б. Лепейко, В. А. Невзорова, Е. А. Гилифанов [и др.] // Сибирский научный медицинский журнал. 2015. - T. 35, № 1. - С. 19-27.

\section{REFERENCES}

1. Davidovskiy, I.V. (1962). Problema prichinnosti v meditsine (etiologiya) [Causation issues in medicine (etiology)]. Moscow: Medgiz [in Russian].

2. Sarkisov, D.S., \& Remezov, P.I. (1960). Vosproizvedenie bolezney cheloveka v eksperimente [Experimental reproduction of human diseases]. Vishnevskiy, A.A. (Ed.). Moscow [in Russian].

3. Leytes, A., \& Shidakov, Yu. (1972). Plastichnost krovenosnykh sosudov serdtsa i legkikh [Flexibility of blood vessels of the heart and lungs]. Kirgizstan: Frunze [in Russian].

4. Shlyakhover, V.E., Yabluchanskiy, N.I., \& Shevchenko, V.I. (1983). Kolichestvennaya harakteristika strukturnoy organizatsii miokarda sobaki [Quantitative characteristics of the structural organization of the myocardium of a dog]. Krovoobrascheniye - Blood Flow, 16 (2), 3-6 [in Russian].

5. Schaper, G., Meiser, E., \& Stammler, G (1985). Ultrastructural morphometric analysis of myocardium from dogs, rats, hamsters, mice and from human hearts. Circ. Res., 56 (3), 377-391.

6. Kiptenko, L.I., Vasko, L.V., \& Hortynska, O.M. (2013). Morfolohichni zminy vnutrishnikh orhaniv shchuriv v umovakh klitynnoi dehidratatsii na tli postravmatychnoi rehene-

ratsii velykohomilkovoi kistky [Morphological changes of internal organs of rats under condition of cell dehydration on the background of post-traumatic regeneration of tibia]. Svit medytsyny ta biolohii - World of Medicine and Biology, 2, 41-43 [in Ukrainian].

7. Netiukhailo, L.H., Filatova, V.L., \& Filatova, O.V. (2012). Vodno-soliovyi obmin (ohliad literatury) [Watersalt metabolism (literature review)]. Visnyk problem biolohii i medytsyny - Journal of Problems of Biology and Medicine, 1 (91), 28-33 [in Ukrainian].

8. Sapozhnikov, O.P., \& Maksymova, O.S. (2015). Morfolohichni i ultrastrukturni zminy u leheniakh shchuriv molodoho viku za umov vplyvu zahalnoi dehidratatsii [Morphological and ultrastructural changes in the lungs of rats of younger age under the impact of general dehydration]. Morfolohichni doslidzhennia - vyklyky suchasnosti. Zbirnyk tez dopovidei Naukovo-praktychnoi konferentsii - Morphological Studies - Challenges of Modernity. Collection of Reports of Scientific and Practical Conference. April 23-23, 2015. Sumy: Sumy State University [in Ukrainian].

9. Zaiko, M.N., \& Bytsio, Yu.V. (Eds.). (2008).Patofiziolohiia [Pathophysiology]. Kyiv: Medytsyna [in Ukrainian]. 
Огляди літератури, оригінальні дослідження, погляд на проблему, ювілеї

10. Nahornaya, N.V. Seminar: toksikozy u detey [Seminar: toxicosis in children]. Zdorovye rebenka - Health of a Child, 1 (28), 7-15 [in Russian].

11. Bumeister, V.I. (2009). Elektronnomikroskopichna kartyna reheneratu velykohomilkovoi kistky shchuriv za dii pozaklitynnoho znevodnennia [Electromicroscopic image of the regenerate of rat tibia under the impact of extracellular dehydration]. Klinichna ta eksperymentalna patolohiia - Clinical and Experimental Pathology, 8 (2), 1013 [in Ukrainian].

12. Guseynova, S.T. (2009). Morfologicheskie izmeneniya $v$ imunnykh obrazovaniyakh tonkoy kishki pri degidratatsii i korrektsii fizrastvorom [Morphological

changes in immune formations of small intestine under condition of dehydration and correction with physical solution]. Vestnik novykh meditsinskikh tekhnologiy Journal of New Medical Technologies, 16 (2), 199-200 [in Russian].

13. Lepeyko, Yu.B., Nevzorova, V.A., \& Gilifanov, E.A. (2015). Izmenenie aktivnosti neyrokininovoy sistemy $v$ slizistoy obolochke verhnikh dykhatelnykh putey krys pri modelirovanii khronicheskogo tabakokureniya [Dynamics of neurokinin activity in the mucosa of upper respiratory tract of rats in modeling of chronic tobacco smoking]. Sibirskiy nauchnyy meditsinskiy zhurnal - Siberianm Scientific Medical Journal, 35 (1), 19-27 [in Russian].

\title{
ОСОБЕННОСТИ СТРУКТУРНО-ПРОСТРАНСТВЕННОЙ ОРГАНИЗАЦИИ КРОВЕНОСНОГО РУСЛА ЛЕГКИХ КРЫС В НОРМЕ И ЕГО РЕОРГАНИЗАЦИЯ ПРИ ОБЩЕМ ОБЕЗВОЖИВАНИИ
}

\author{
Гвуз «Тернопольский государственный медицинский университет имени И. Я. Горбачевского \\ МЗ Украины»
}

РЕЗЮМЕ. Экспериментальное моделирование различных заболеваний на животных является одним из основных методов изучения закономерностей развития патологических процессов, часто встречающихся в клинической практике. При этом с целью объективной сравнительной оценки экспериментальных данных и их последующей экстраполяции на человека важно знать основные морфометрические параметры органов и тканей в норме. Что касается общего обезвоживания, то оно возникает вследствие самых разнообразных физиологических и патологических состояний и может быть причиной тяжелых нарушений в различных органах, включая легкие.

Цель исследования - установить особенности структурно-пространственной организации кровеносного русла легких крыс в норме и дать количественную характеристику изменений его отдельных параметров при общем обезвоживании.

Материал и методы. Эксперименты проведены на белых лабораторных половозрелых крысах-самцах которым моделировали общую дегидратацию разной степени тяжести. Исследования проводились с использованием рентгенангиографических, гистологических, морфофметрических и статистических методик.

Результаты. По результатам проведенного исследования были установлены определенные видовые особенности структурной организации легочной ткани и кровеносного русла легких у крыс и дана их количественная оценка. К этим особенностям относится соотношение между правым и левым легким по объему и массе, разделение на доли каждого из легких и соответствующее ветвление их кровеносных сосудов. Особенностью является также достаточно частое выявление артерий «замыкающего» типа. При длительном общем обезвоживании отмечено восходящую вазоконстрикцию с одновременным снижением пропускной способности ветвей легочных артерий мелкого и среднего калибра и расширением просвета с увеличением емкости крупных интраорганных артерий.

Выводы. 1. У крыс правое легкое по объему и массе значительно преобладает над левым и их соотношение составляет 2,22 к 1,00. 2. Особенностью легких крыс является их разделение на доли: правая делится на 4 доли, в левой долевое деление не выражено, что определяет особенности ветвления правой и левой легочных артерий. 3. Длительное общее обезвоживание приводит к снижению пропускной способности кровеносных русел легких за счет повышения тонуса и сужения просвета ветвей легочных артерий мелкого и среднего калибра, а также бронхиальных артерий, с одновременным расширением просвета и увеличением емкости крупных интраорганных артерий.

КЛюЧЕВЫЕ СЛОВА: експеримент; норма; общее обезвоживание; легкие; артерии; морфометрия. 


\title{
Огляди літератури, оригінальні дослідження, погляд на проблему, ювілеї
}

\section{FEATURES OF STRUCTURAL-SPATIAL ORGANIZATION OF THE BLOOD CHANNELS OF RAT LUNG NORMALLY AND ITS REORGANIZATION IN GENERAL DEHYDRATION}

\author{
@M. O. Vatsyk
}

\section{Horbachevsky Ternopil State Medical University}

SUMMARY. Experimental animal modeling of various diseases is one of the main methods of studying the patterns of development of pathological processes that are common in clinical practice. At the same time, in order to objectively compare the experimental data and their subsequent extrapolation to a person, it is important to know the basic morphometric parameters of organs and tissues in the norm. As for general dehydration, it arises due to a wide variety of physiological and pathological conditions and can cause severe violations in various organs, including lungs.

The aim of the study - to determine the peculiarities of the structural and spatial organization of the blood channel of lungs of rats in norm and give a quantitative description of changes of its separate parameters at the general dehydration.

Material and Methods. Experiments were carried out on white laboratory sexually-mature male rats, which modeled general dehydration of different degrees of severity. The research was carried out using X-ray diffraction, histologic, morphometric and statistical techniques.

Results. According to the results of the study, certain specific peculiarities of the structural organization of the pulmonary tissue and the bloodstream of the lungs in the rats were determined and their quantitative assessment was made. These peculiarities include the ratio between right and left lungs by volume and mass, division each lung for lobes and the corresponding branching of their blood vessels. A peculiarity is also a rather frequent detection of arteries of the "locking" type. At prolonged general dehydration, ascending vasoconstriction with the simultaneous decrease in the throughput of branches of small and middle caliber pulmonary arteries and enlargement of the lumen and increase of capacity of intra-organ arteries of large caliber were noted.

Conclusions. 1. In rats, the right lung predominates much to the left in terms of volume and mass and their ratio is 2.22 to 1.00. 2. The peculiarity of the lungs of rats is their division into lobes: the right is divided into 4 lobes, the left lobe division is not expressed, which determines the features of the branching of the right and left pulmonary arteries. 3. Prolonged general dehydration leads to the decrease in the flow capacity of bloodstream of the lungs due to increased tone and narrowing of the lumen of the branches of the small and middle caliber pulmonary arteries, as well as of the bronchial arteries with the simultaneous enlargement of the lumen and the increase in the capacity of the intranasal arteries of large caliber.

KEY WORDS: experiment; norm; general dehydration; lungs; arteries; morphometry.

Отримано 11.08.2018 